\title{
Absent Voices: Women and Youth in Communal Land Governance. Reflections on Methods and Process from Exploratory Research in West and East Africa
}

\author{
Stefanie Lemke *(D) and Priscilla Claeys $(D)$ \\ Centre for Agroecology, Water and Resilience, Coventry University, Ryton Gardens, Wolston Lane, \\ Ryton-on-Dunsmore, Warwickshire CV8 3LG, UK; priscilla.claeys@coventry.ac.uk \\ * Correspondence: stefanie.lemke@coventry.ac.uk
}

Received: 30 June 2020; Accepted: 7 August 2020; Published: 10 August 2020

\begin{abstract}
An increasing number of African States are recognizing customary land tenure. Yet, there is a lack of research on how community rights are recognized in legal and policy frameworks, how they are implemented in practice, and how to include marginalized groups. In 2018-2019, we engaged in collaborative exploratory research on governing natural resources for food sovereignty with social movement networks, human rights lawyers and academics in West and East Africa. In this article, we reflect on the process and methods applied to identify research gaps and partners (i.e., two field visits and regional participatory workshops in Mali and Uganda), with a view to share lessons learned. In current debates on the recognition and protection of collective rights to land and resources, we found there is a need for more clarity and documentation, with customary land being privatized and norms rapidly changing. Further, the voices of women and youth are lacking in communal land governance. This process led to collaborative research with peasant and pastoralist organizations in Kenya, Tanzania, Mali and Guinea, with the aim to achieve greater self-determination and participation of women and youth in communal land governance, through capacity building, participatory research, horizontal dialogues and action for social change.
\end{abstract}

Keywords: gender; women and youth; communal land governance; right to land; collective rights; participatory action research; transdisciplinary approach; COVID-19; West and East Africa; constituencies

\section{Introduction}

After a long and intense process of negotiation involving representatives from peasant organizations, pastoralists, fisherfolk, agricultural workers and Indigenous Peoples from all over the world, the United Nations (UN) Declaration on the Rights of Peasants and other people working in rural areas (UNDROP) was adopted by the UN General Assembly in December 2018 [1]. This new international legal instrument represents a key milestone in the struggle for food sovereignty and people's control over land and natural resources. The Declaration recognizes, for the first time, the human rights to land, seeds, biodiversity and food sovereignty. In the Declaration, these rights are recognized not only as individual, but also as collective rights.

The topic of collective human rights was extremely controversial during the negotiations. Discussions around the right to land, as observed by Priscilla Claeys who conducted participant observation during the negotiation process at the UN Human Rights Council between 2012 and 2018 [2], revealed conflicted views and visions about the management and governance of land, but also the meanings, values and relations between rural people and their land. Representatives of rural constituencies insisted that a great proportion of the world's land and natural resources continues to be 
managed collectively. They called on alternatives to private property, and denounced land grabbing. They also stated that rural communities, especially women, are often dependent on commons, such as pastoral land, forests or rangelands for their livelihoods, as has been shown by other authors [3,4].

These claims were met with resistance by several states [2]. Some diplomats argued that human rights are inherently individual rights, while others stated that nothing justifies granting special rights to peasants as a group. It was also stated that the only collective right recognized in international human rights law was the right to self-determination and that collective rights could not be recognized for any other group than Indigenous Peoples. Peasant and other rural organizations responded that they exist as a group, because they endure systemic and systematic discriminations as a group, and that without their rights to land, seeds, biodiversity and food sovereignty, they would not be able to continue feeding their communities and the world at large. Their voice was heard, and, to a large extent, the Declaration meets their demands and expectations, including that of being recognized as a collective, political subject and rights-holder [2].

Having long worked on topics relating to food sovereignty, the right to food, food governance, agrarian movements, nutrition and gender dynamics, we were excited by this development and eager to support the implementation of the Declaration [5-10]. We wanted to better understand, and document, how collective rights are experienced and implemented in practice, and how the rights of communities that depend on land, seeds and natural resources for their livelihoods could be better protected. We were particularly interested in exploring these issues in Africa, considering the prevalence of communal rights regimes in the continent. Customary tenure is estimated to be the dominant form of tenure over 78 per cent of Africa [11,12]. We felt that lessons could be drawn from efforts to codify and protect communal land rights in the face of growing appropriation of land and nature, that could inform struggles elsewhere.

As scholar-activists, we wanted to co-develop the research agenda with peasant organizations and other rural constituencies, and the research process and outcomes to be useful for local actors in their ongoing struggles to advance the right to land and other natural resources on the continent. Yet, the constraints associated with most research grants are such that developing a research agenda from the bottom-up is rarely possible. Based on our experience of many years in research funders usually require pre-determined project goals, assumed outcomes and impact measures at the stage of applying for funding. This limits the possibility of engaging in truly participatory and transdisciplinary approaches that would enable all partners to co-develop research priorities and research processes from the initial conception phase. To be able to do this requires establishing trustful relationships among research partners, respecting each other's worldviews, as well as overcoming unequal power relations between 'conventional sciences' and alternative knowledge systems [13,14].

With this goal in mind, we approached the 11th Hour Project, which we knew was sympathetic to the food sovereignty movement in Africa, and counted several food sovereignty actors in its list of grantees. We pitched our idea and approach, and were successful in obtaining seed money to initiate an exploratory research process on Governing Natural Resources for Food Sovereignty in West and East Africa. We were able to draw on a long and rich tradition of Participatory Action Research (PAR), which basically involves researchers and local actors working together to understand a problematic situation and change it for the better, following an iterative cycle of research, action and reflection [15-17].

In this article, we report on the methods, process and outcomes of this project, which we conducted from February 2018 to July 2019. Section Two provides detailed insights into the research process and participatory methodology used. Section Three presents key outcomes emerging from this process, and how it helped us collectively identify an important research gap around gender and communal land. Section Four briefly outlines our new research project on women's communal land rights. 


\section{Research Process and Methods}

In this section, we reflect on the successive steps that led us to adopt our current new research focus on women's communal land rights. We place emphasis on the process and the methodologies we used, with a view to sharing lessons learned, as well as some critical reflections moving forward.

\subsection{Establishing Networks in West and East Africa}

Right from the start, we envisioned some kind of comparative research involving organizations from both West and East Africa. Despite differences regarding colonial histories, legal and policy frameworks, and the extent to which customary rights are recognized in law, the issues affecting customary land tenure regimes are shared across the two regions. In addition, many representatives from peasant and other rural organizations know each other from attending organizational events, be it international fora or UN processes (such as the UN Committee on World Food Security, CFS; the Food and Agriculture Organization, FAO; the International Fund for Agricultural Development, IFAD; or the International Convention on Biodiversity, CBD). We further felt it would be valuable to enable mutual learning between the two regions. Yet, communications between food sovereignty/agrarian networks are limited, partly due to language barriers.

We conducted an initial desk-review to select potential case studies-cases of legal mobilizations to protect/defend collective/communal land rights_-but found it difficult to identify relevant experiences as there is little documentation readily available on the internet.

Through key contacts in both regions, obtained via our professional and academic networks (including the Civil Society and Indigenous Peoples' Mechanism (CSM) for relations with the CFS, the human rights network FIAN International, the Coalition of European Lobbies for Eastern African Pastoralism (CELEP) and academics in the region), we liaised with a variety of actors. Our approach was to organize two workshops, one in each region, to identify potential partners and research priorities.

We co-organized the first workshop in West Africa with the Institute for Research and Promotion of Alternatives in Development (Institut de recherche et promotion des alternatives en développment (IRPAD), a progressive think-tank and action research center. We selected IRPAD for our longstanding collaboration with its Director Mamadou Goïta who is connected to global and regional actors and processes and was involved as expert panelist in the process of negotiation of the UNDROP. In East Africa, our local partner organization was the Alliance for Food Sovereignty in Africa (AFSA). We selected AFSA for its reputation and ability to bridge with various networks at both global and regional level. We had already established a connection with its Director Million Bellay, who was also involved as expert panelist in the process of negotiation of the UNDROP.

A field trip to Mali in March 2018 enabled us to meet with the IRPAD team and plan for the workshop that we co-hosted with them in June of the same year. We discussed the methodology, which questions to discuss collectively and were able to rely on Mamadou Goïta's extensive network to identify potential participants. In addition, we were able to connect with the National Federation of Peasant Organizations (Confédération nationale des organisations paysannes, CNOP), and the Women's Coalition for Food Sovereignty (Coalition des Femmes pour la souverainetéalimentaire, COFERSA). We were privileged to attend a two-day forum in Segou with more than 400 farmers and communities from across Mali affected by landlessness and appropriation of land, organized by the grassroots Malian Convergence against Land Grabbing (Convergence malienne contre les accaparemments de terre, CMAT). Our trip to Mali proved extremely useful to understand the issues underlying the protection of community rights in the country. It also enabled us to interview people who had been driving the process of drafting and adoption of the new Agrarian Land Law, which recognizes the possibility for community rights over land to be managed at the village level [18].

A second field trip to Uganda in January 2019 enabled us to meet with AFSA and plan for the workshop that we co-hosted in March of the same year. We discussed workshop objectives with the AFSA team and shared insights from the first workshop we had co-organized the year before. In addition to co-designing the workshop with AFSA, we were able to connect with a number of agrarian 
organizations, NGOs and academics working on land, including the Eastern and Southern Africa Small Scale Farmers' Forum ESAFF - UGANDA, Katosi Women Development Trust (KWDT), progressive lawyers from the University of Makarere and the Advocates for Natural Resources \& Development ANARDE, and FIAN Uganda.

\subsection{Participatory Workshops in Mali and Uganda}

Participants at the two workshops represented a diversity of voices from the food sovereignty movement in the two regions, while opening opportunities for dialogue between actors who may be in different networks and do not often speak to each other. We took great care in elaborating the methodology for the two workshops. The first step was elaborating the participants' lists, in partnership with IRPAD for West Africa and AFSA for East Africa. For the first workshop, in Bamako, we paid attention to gender as well as regional balance, and invited organizations from Benin, Burkina Faso, Guinea, Mali, Niger and Senegal. We also made sure to invite a mix of representatives from peasant organizations, pastoralists/herders, NGOs and lawyers, as well as academics. For the second workshop, in Entebbe, we similarly applied a regional quota to have a good balance of participants from Ethiopia, Kenya, Tanzania and Uganda, respectively. We ensured gender parity with a view to guarantee the strong participation of women. In addition, we ensured a diversity of constituencies, representing small scale farmers' organizations, pastoralists, fishers and Indigenous Peoples, as well as some NGOs, feminist/women's rights' organizations, academics and progressive human rights lawyers.

Efforts to ensure a diversity of constituencies and address power dynamics among participants were inspired by research conducted by Priscilla Claeys and Jessica Duncan [19] on the mechanisms used by actors in the Global Food Sovereignty Movement to facilitate convergence and unity in diversity. Actors in this movement have long tried to prioritize the voice of peoples' organizations over that of NGOs, to enable affected constituencies to directly participate in food governance and not let others speak on their behalf [20]. Complex mechanisms balancing regions, gender, generations and constituencies are used in the Civil Society Mechanism to the UN Committee on World Food Security, for example, to enable participants to speak with one voice while protecting/fostering separate identities (for a historical overview of how constituencies developed within the Global Food Sovereignty movement and how they are applied in the CSM see $[19,21]$. Critically reflecting on our efforts to be as inclusive as possible, we are aware of the fact that we mostly engaged with members of organizations and social movements who are in a more privileged position. In other words, the most affected did not attend our workshops. This is partly due to the fact that we identified participants through international networks (and accessing these networks requires considerable social and political capital, including mastering several languages). This might result in missing the voices of those who are most marginalized. In follow-up research, an important task in collaboration with our partner organizations will be to ensure that they reach out to those who are usually excluded so as to fully take into account the various power relations and potential conflicts between various users of land and other natural resources (as addressed in both workshops by Axis 3 and Axis 4).

We applied participatory and horizontal methodologies to ensure the full and active participation from all participants, such as the World Café and the Fishbowl (see Figures 1 and 2). 


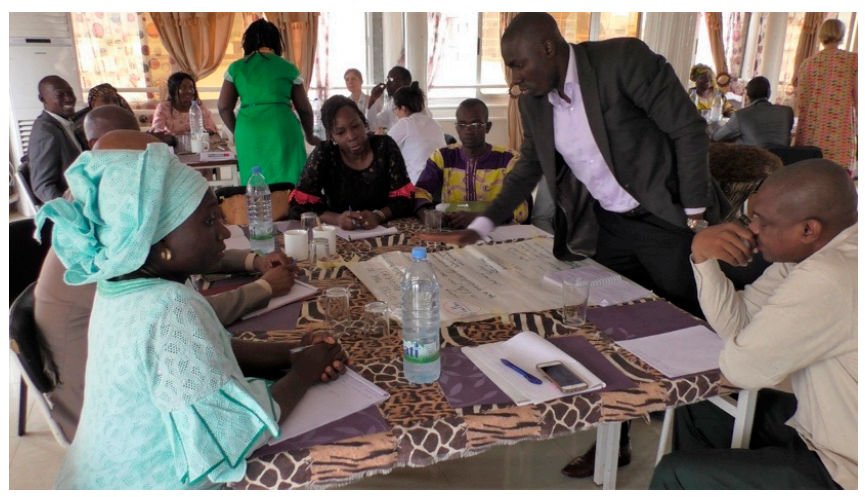

(a)

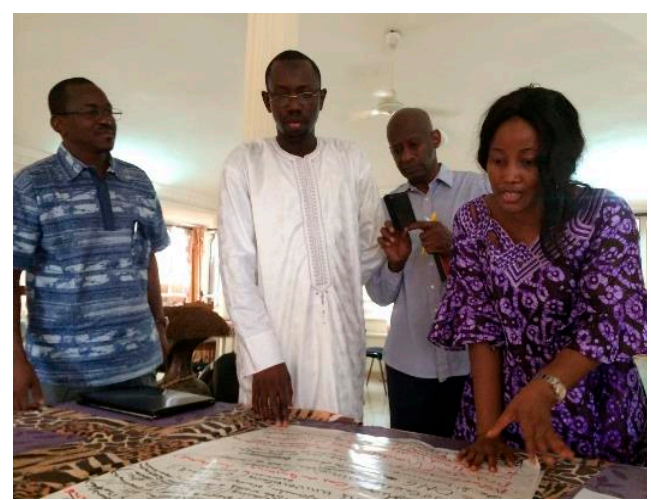

(b)

Figure 1. World Café, Workshop Bamako, Mali, June 2018. (a) Discussions at the three tables; (b) summarizing key points emerging from discussions for the next group of particpants. Photos: Ann-Christin Weiler (a) and Stefanie Lemke (b).

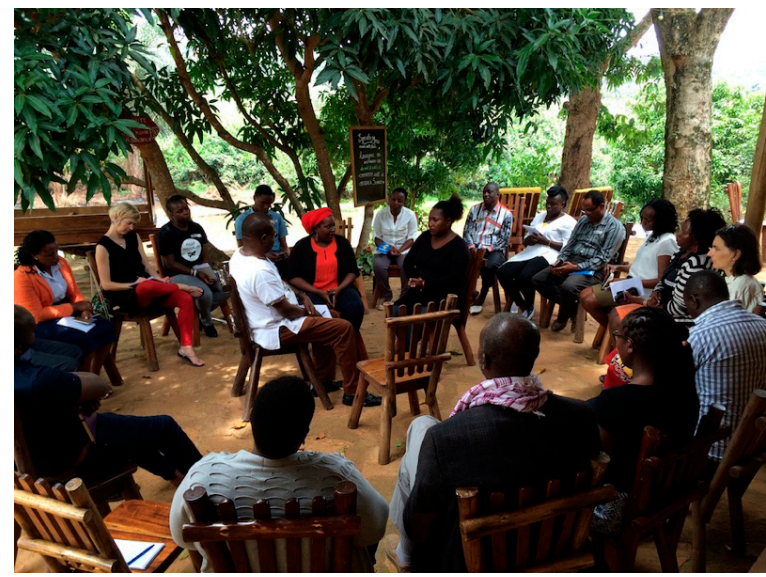

(a)

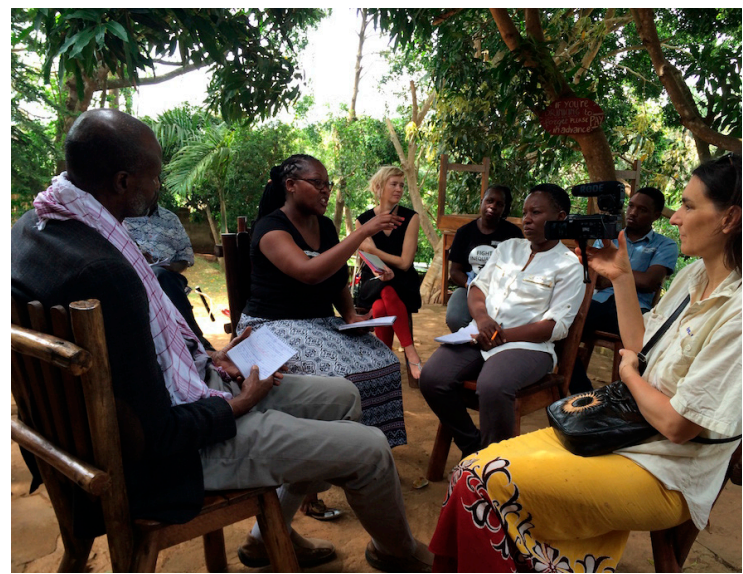

(b)

Figure 2. Fishbowl, Workshop Entebbe, Uganda, March 2019. (a) Arrangement of the outer and inner circle, the 'fishbowl', one chair remains empty; (b) filming discussions in the 'fishbowl'. Photos: Stefanie Lemke.

In the World Café, participants are divided into three tables. Each table is assigned a facilitator. The facilitator introduces the question and initiates the discussion. Everyone at the table exchanges ideas for about $20 \mathrm{~min}$. Then, participants move on to the next table, except for the facilitator. He/she shares with the second group the ideas developed by the first group. Rather than starting from scratch, the second group thus builds on the ideas that were collected. After $20 \mathrm{~min}$, the three groups move again to the next table. In the end, all participants go from table to table, listen to the facilitator's report and add information or ask questions [22].

In the fishbowl, four to five chairs are arranged in an inner circle, the 'fishbowl'. The remaining chairs are arranged in a circle outside the fishbowl. Participants are selected to fill the fishbowl; the rest of the group sit on the chairs outside the fishbowl. One chair is left empty. The moderator introduces the topic and the participants start discussing the topic. The audience outside the fishbowl listens in on the discussion. Any member of the audience can, at any time, occupy the empty chair and join the fishbowl. When this happens, one person in the fishbowl must voluntarily leave and free a chair. The discussion continues with participants entering and leaving the fishbowl [23].

We approached participants to ask if they would agree to take turns in facilitating sessions. This role involved organizing the discussion, managing speaking times, ensuring everyone can speak, taking notes on flipcharts and sharing outcomes with the larger group. Most participants got to 
facilitate a session, which allowed us to share tasks and also created a sense of collective ownership over the process and its outcomes.

The methodology was very much appreciated by participants and enabled in-depth discussions and interactions. Our perception was that the strong presence of women enabled them to make their voices heard. We observed mild tensions initially when starting discussions around women's rights and gender. For example, several participants made jokes or comments about the great number of women present. However, these tensions quickly dissolved, thanks to the participatory format that encouraged everyone to engage. Participants shared how they had made new contacts and networks; how lively and relaxed the atmosphere was; how they connected with others at a deep and personal level; how they enjoyed the open, efficient and involving methodology that makes it impossible NOT to participate; and how several of them were aiming at replicating the fishbowl and world café methodologies in their own work.

Our only regret was to have failed to achieve adequate representation of the youth in both workshops. This was due to the fact that we had not considered this enough at the invitation stage, and also because it is difficult for young people to achieve leadership positions in organizations, and to be nominated to represent their organization at workshops or events. Based on this experience, we concluded that we need to better include the youth in future, both in the process and in our research. This was stated also by our research partners in follow-up conversations.

Through our initial discussions with Mamadou Goïta, we had identified five main axes to guide our discussions. We used the same five axes in both workshops:

- Axis 1: a collective mapping exercise to identify ongoing struggles for collective rights to land, seeds and other natural resources;

- Axis 2: a collective mapping of the legal and policy frameworks that currently recognize collective/community rights to land, seeds and natural resources;

- Axis 3: a discussion of relations of power within community rights systems, and how to address the marginalization and the needs of specific groups. We paid specific attention here to women and youth, but also to other groups that we collectively identified, such as fishers or pastoralists;

- Axis 4: a discussion of the conflicts that may arise between various users of land and natural resources, and effective mechanisms to address these;

- Axis 5: future collaboration and processes to collectively identify gaps in research and action that could support movement struggles.

In a final feedback round participants commented on how they perceived the workshop process, methods and outcomes. Participants highlighted how much they had learned from each other, for example on pastoralism, seeds, fishing or struggles against mining; how useful they found it to reflect on the legal aspects of community land issues; how the information they got at the workshop could not have been found anywhere else, as this information is not available in books or on the internet; how they discovered opportunities for collaboration at regional level; and how the voices of pastoralists, fishers and women are still struggling to emerge in food sovereignty discussions and that this workshop was a great opportunity to engage on these issues.

\subsection{Desktop Study}

In parallel, we commissioned a desktop study of legal and policy frameworks in both regions, entitled "Governance of land and natural resources in Africa. Overview of legal and policy frameworks on collective/customary land tenure; marginalization; and conflicts", conducted by our colleague, Stefania Errico [24]. The objective of this study was to undertake:

- a preliminary analysis of the extent to which collective rights to land, seeds and natural resources (including customary rights and the commons) are recognized and protected in legal and policy frameworks in Western and Eastern Africa; and, 
- a first identification of the key factors that may have an impact on the realization of collective rights to resources in these regions and consequently on the potential contribution of collective rights to equitable and resilient food systems.

The desktop study followed the logic of the five axes developed for the two workshops, and focused on the following three main sections: 1. mapping of legal and policy frameworks (Axis 2); 2. power relations and the rights of specific groups (women, youth, marginalized groups) (Axis 3); and 3. the rights of different rural constituencies and potential conflicts between different users of land and natural resources (Axis 4). The study provided more analysis and background on some of the key issues that had emerged in the workshops, and helped to identify gaps in research based on a review of the literature.

\subsection{Video Documentation}

We documented both workshops through video filming, photographs, audio recording and extensive notes. We were assisted in filming by Marine Lefebvre from SOS Faim Luxembourg and two Masters students based at the University of Hohenheim, Germany. Back in the UK, we created a series of short movies, in French and in English, and a full movie comprising all short movies. We had no prior experience with this and really enjoyed the creative process that entails drafting a script, and watching and selecting hours of footage. We quickly realized we would need to complement the footage we had with some graphic animation. Further, we were very lucky to have Stéphane Parmentier compose some beautiful music for us, mixing traditional African and electronic tones. We also benefited from exchanges with our colleagues at the Centre for Agroecology, Water and Resilience, Coventry University (CAWR) who gave us very useful feedback through the editing process.

In the full movie (see link in Supplementary Materials), the introductory section presents the objectives of the project and situates it within the broader context of struggles around natural resources and why community rights matter, making the link with the UN Declaration on the Rights of Peasants and other people working in rural areas. Our intention with the movies was to illustrate both workshop process and interactions as well as outcomes. The methodologies applied to facilitate horizontal discussions on sensitive topics are documented in detail, due to the feedback received by workshop participants who highlighted that our approach was innovative and that they were hoping to use this type of approach and some of the methods applied in their own work. We decided to mix footage from Mali and Uganda as a way to highlight commonalities, but also differences between the two regions, and to enable a sharing of experiences and learning from each other.

\section{Results}

\subsection{Key Outcomes of Exploratory Research}

The two workshops in Mali and Uganda and the supporting desktop study "Governance of land and natural resources in Africa. Overview of legal and policy frameworks on collective/customary land tenure; marginalization; and conflicts" [24] served to collectively identify key achievements and challenges with regard to governing natural resources in the two broader regions, as well as identifying key areas for future research.

Among the key achievements in protecting collective rights to resources are:

- growing recognition of community land rights in the law and in policy agendas;

- social movement mobilizations in defense of communal land rights (mainly in West Africa);

- multi-actor platforms for dialogue with governments;

- progressive human rights lawyers working with peasant and pastoralist organizations (mainly in East Africa).

Among the key challenges in protecting collective rights to resources are: 
- declining natural resources and biodiversity, climate change, and growing conflicts over land;

- commercialization (large-scale land deals), privatization and selling of land, elite capture;

- focus on individual titling to protect tenure security, which may result in women losing land;

- power dynamics and marginalization, with women and the youth being largely excluded from communal land governance;

- lack of legal protection of communal land rights and tensions between customary and national law. For example, while gender equality is part of many constitutions, this is not implemented in practice.

These findings were supported by the desktop study [24], showing that the main obstacles to the respect, protection and realization of collective/customary land rights include biased approaches against certain forms of land use, contradictory laws and policies, the absence of mechanisms and capacity to ensure the actual implementation of relevant pieces of legislation recognizing customary rights and the weakening of traditional authorities, in a context marked by increasing pressure on customary lands. As the desktop study further revealed, the commodification and individualization of land rights have occurred within customary systems, as a result of increasing land value and market integration, and have had a repercussion, among others, on communities' cohesion and their capacity to speak with one voice on land matters and defend their rights 'collectively'. Tenure insecurity and the growing marginalization of certain groups remain crucial sources of conflicts throughout the continent, whether they occur between local resource users or with external actors [12,25-28].

The key areas identified by participants for future research and much needed documentation, in partnership with peasant, fisherfolk, pastoralist and Indigenous Peoples' organizations, include:

- ongoing struggles by peasant, fisherfolk, pastoralist and Indigenous Peoples' organizations to defend these rights;

- how community/customary rights over land and natural resources operate in practice and how they have evolved over time;

- the extent to which community rights are protected in the law and the impact of various institutional setups on their enjoyment;

- local and traditional knowledges for communal natural resource management;

- local strategies for climate change adaptation and resilience;

- obstacles and opportunities for the participation of women, youth and other marginalized groups in communal resource management and policy-making in general.

The desktop study [24] equally emphasized the need for more research on how customary regimes are changing and evolving at a rapid rate. In the context of current debates on the recognition and protection of customary/collective rights to land and resources, there is a need for more clarity and documentation of customary practices. Particular attention needs to be paid to marginalized groups, including women, youth and Indigenous Peoples. With regard to the youth, there are growing efforts by youth organizations in relation to access to land and other natural resources, which seek to address the lack of perspectives and future livelihoods in rural areas. More research is also needed on gendered use of common resources within collective tenure and the norms of their allocation and use.

\subsection{Reflecting on Key Research Outcomes and Process, Co-Designing Follow-Up Research}

Reflecting on the main learning points from this process during the fall of 2019, a major takeaway for us was the lack of a women's voice on communal land governance. From what was shared with us by workshop participants, it was clear that land issues continue to be seen as the domain of men, with women and the youth being largely excluded from land governance decisions. The absence of a women's voice in land governance was of course nothing new. What we found most intriguing however was the "return" of customary regimes on the agenda of key actors in the food sovereignty movement, such as the Malian national peasant organization CNOP and the Alliance for Food 
Sovereignty in Africa (AFSA). Their insistence on promoting and defending communal land ownership, in lieu of private and absolute property, echoed efforts by agrarian movements involved in the negotiations of the UNDROP to achieve recognition of the right to land as an individual and collective right. Just as their international allies were making a strong case for collective rights at the Human Rights Council, the actors we talked to at our workshops were advocating for the legal recognition of communal land rights (CLR), because they see this as key to protecting communities against land grabbing. Yet, we also found that actors in these movements do not all equally emphasize the importance of ensuring inclusivity in communal land governance and the participation of all community members in decisions concerning the land. Even in these progressive food sovereignty movements, women's rights can be marginalized, as we witnessed when engaging with actors who had advocated for the new Agrarian Land Law in Mali. One of them explained to us that their first priority is to secure communal land rights, and that the position and 'participation' of women in this process will be dealt with later. Again, this resonated with debates held during the negotiations of the UNDROP. While women's rights to land are recognized in the Declaration, there are important limitations in the text concerning their rights to inherit land [29], and it will be particularly important to monitor the implementation of the UNDROP on this point. The participation of the youth in communal land governance is similarly lacking although there is great awareness of the need to do more in this area.

Between November 2019 and February 2020, we conducted a series of follow-up interviews with representatives from selected partner organizations, with the aim to co-develop a more focused research theme. The limited decision-making power of women and the youth within communal land governance was confirmed during interviews, but what emerged strongly was the need to do more action research on the lacking intersection between gender and communal land rights, in partnership with peasant and pastoralist organizations. Turning to the literature, we found there was very little to build on, especially considering rapidly changing gender dynamics and customary regimes. While some of these processes might be documented by organizations working on these issues, this type of information is often not easily available.

In the next section, we shortly present the new research project which was approved by the 11th Hour Project in June 2020 and will take place over the next 18 months, with a focus on women's communal land rights.

\section{New Research Project on Women's Communal Land Rights (WCLR)}

\subsection{Project Rationale}

The gender-communal land rights nexus deserves more attention for four reasons. First, efforts by development actors have focused on enabling women to acquire or work on the land individually. This is however particularly problematic in Africa, where most of the land is under customary tenure, and where access to collectively held land is essential to women's livelihoods. Second, in most customary land systems in Africa, women are still not recognized independent rights to land and they rarely participate in decisions about communal land governance (CLG). In practice, they gain access to them through their relationship with a male relative (usually the husband or father) [25-27]. Women are rarely compensated for their losses in case of land dispossession, and may lose access if the relationship no longer exists (in case of divorce or death of the husband). In addition, customary institutions are rapidly changing, and the traditional norms that used to ensure that women would have access to land are no longer enforced or in place. Third, communal land rights are increasingly being turned into individual plots that are sold to investors, triggering intra-household competition between men and women - and between generations-over productive resources. In many places, women are losing access to land as a result of the family property being privatized by senior male members, a phenomenon known as 'family land grabbing' [30]. Fourth, efforts to provide secure land tenure for communities through the formalization of communal land ownership, while valuable and 
important, often have negative outcomes for women, as their interests are not properly considered in the implementation of state programs to strengthen collective tenure [28].

\subsection{Project Partners, Objectives and Research Priorities}

We selected four partners for this project, all of them peasant (women) or pastoralist organizations. It was important to us to prioritize grassroots organizations over NGOs. We decided to focus on two countries in West Africa: Mali and Guinea, and two countries in East Africa: Kenya and Tanzania. Reflecting on the size and format of this new project, we started with a small group to be able to build this process slowly, with the aim to expand and include other partners at a later stage.

The main project partners are:

- Kenyan Peasants League (KPL), a peasant organization in Kenya established in 2016 and member of La Via Campesina, which promotes peasant farming and agroecology;

- Pastoral Women's Council (PWC), a pastoralist women's organization created by Maasai women in 1998, Tanzania, to defend the rights of pastoralist women and girls;

- CNOP-G, the national confederation of peasant organizations in Guinea (a member of ROPPA and COPAGEN), set up in 2000 to defend the interests of peasants and which represents 700,000 family farms, with a membership of 52 per cent women;

- COFERSA, the national coalition of women for food sovereignty, a network of 45 women's cooperatives gathering more than 4000 women across Mali, established in 2009.

The overarching objective of this project is to draw lessons from and scale up efforts to advance WCLR (in East and West Africa). The project will rely on four main areas of work (Figure 3):

1. Capacity-building: support efforts at becoming more gender-sensitive and gender-transformative; co-develop capacity to conduct participatory action research (PAR);

2. Participatory Research: document and draw lessons from efforts to advance women's communal land rights (WCLR) in different spaces (household/village level, local government, traditional authorities, district level);

3. Facilitate dialogues: between women and men, across generations, at household (HH) level, among women, among men; identify, create and multiply tools and processes that work to facilitate inclusive and empowering dialogues; create social cohesion;

4. Action for social change: support actions that advance and scale-up WCLR, in line with the individual needs and priorities of the partner organizations. 


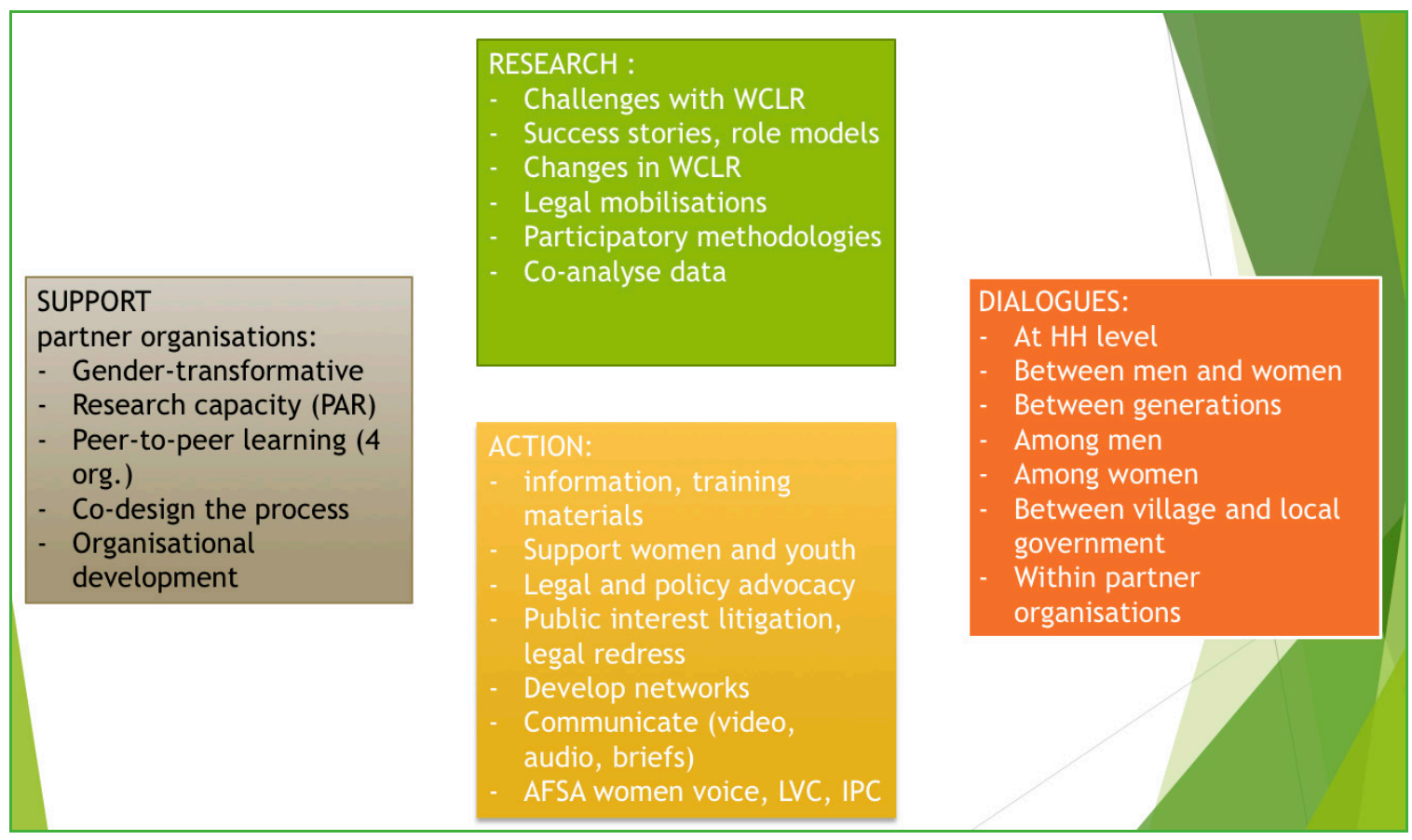

Figure 3. Overview of project goals and the four main areas of engagement outlining project activities.

The four African-based partners have each selected specific focus areas for research. These focus areas have been identified through dialogue to ensure that they align with organizational needs, and address gaps in data and documentation. Research outcomes will be used to support advocacy objectives or be fed into training materials. Each organization will implement a range of activities in relation to the above project goals (see Figure 4).

\begin{tabular}{|l|l|l|l|l|}
\hline Kountry & KPL & PWC & CNOP-G & COFERSA \\
\hline Region & Kenya & Tanzania & Guinee & Mali \\
\hline Key focus & East-Africa & East-Africa & West-Africa & West-Africa \\
\hline $\begin{array}{l}\text { Kidows (and } \\
\text { marginalized } \\
\text { women \& } \\
\text { youth)family land } \\
\text { grabbing }\end{array}$ & $\begin{array}{l}\text { Women's } \\
\text { participation in } \\
\text { governance }\end{array}$ & $\begin{array}{l}\text { Access to land for } \\
\text { women and youth } \\
\text { Key activities }\end{array}$ & $\begin{array}{l}\text { Mapping obstacles and barriers; mapping initiatives and success stories; peer-to- } \\
\text { peer learning; inventory of customary practices/norms }\end{array}$ & $\begin{array}{l}\text { Access to land for } \\
\text { women and youth, } \\
\text { family land } \\
\text { grabbing }\end{array}$ \\
\hline $\begin{array}{l}\text { Legal and policy } \\
\text { advocacy, legal } \\
\text { redress for } \\
\text { widows, PIL }\end{array}$ & $\begin{array}{l}\text { Joint action plan, } \\
\text { advocacy around } \\
\text { land, support } \\
\text { capacity building }\end{array}$ & $\begin{array}{l}\text { Training, advocacy } \\
\text { around land }\end{array}$ & $\begin{array}{l}\text { Training, } \\
\text { awareness raising, } \\
\text { support capacity } \\
\text { building }\end{array}$ \\
\hline
\end{tabular}

Figure 4. Overview of regions, project foci and key activities as elaborated by the four organizations.

The total budget will be shared equally between the five organizations (CAWR and four partners). The Centre for Agroecology, Water and Resilience, Coventry University (CAWR), will be coordinating and supporting project design, implementation and dissemination. There will further be an advisory board to provide feedback and reflections, where several members of the larger network that was established during the previous research will participate. Our aim is to keep close links with all 
partners, and to expand the current research to include other partner organizations. The research process, methodology and outcomes will be shared more widely, for example via an online platform.

The anticipated impacts of this project include: reduced resistance of household members towards women's participation and greater self-determination; reduced resistance of community members towards including women and youth in community land governance; shared understanding at community level of the advantages of broader inclusivity in community land decisions; greater meaningful and active participation of women and young women and men in community land governance; greater visibility of issues affecting women's communal land rights; prioritization of WCLR in agenda-setting by several organizations and networks in the food sovereignty and women's rights and feminist movements.

\subsection{Adapting Our PAR Methodology to the COVID-19 Pandemic}

The final stages leading to the approval of this project took place in the midst of the COVID-19 pandemic. This forced us to reflect further on how we would conduct this research in times of uncertainty and possibly the inability to travel. We decided the pandemic would be an opportunity for us to step back and share even more responsibilities with our partners. The project was always designed as participatory and collaborative. One of the key objectives of this new project is to support our partners with building and reinforcing their own capacity for research, notably through trainings on how to apply PAR methods within their organizations. We will engage in regular dialogue via online platforms, collectively shape the research processes and actions, while giving partner organizations the leadership and responsibility to undertake most of the activities. We are able to do so thanks to the trust we have established over the past two years. By facilitating regular meetings with our project partners for the duration of the project we will ensure clear communication, which will allow for adapting safety measures and project activities if required. As with the preceding project, we will carefully and in a transparent manner document the research and action processes in collaboration with our partners, including the challenges and the opportunities that might arise to build the internal capacity of our local partner organizations in conducting participatory action research.

In addition, all activities conducted during this project will apply safety and hygienic measures as relevant based on the local context, such as: providing and wearing face masks, keeping $2 \mathrm{~m}$ distance, providing soap and water for washing hands, providing sanitizers, limiting the size of groups to maximum 15 people, facilitating meetings outside as much as possible, and avoiding spreading the virus from urban to rural areas. We will further closely monitor and adhere to the respective national guidelines regarding safety measures in the five participating countries.

Finally, we will travel less and better. Even before COVID-19, we had decided to limit our flights and $\mathrm{CO}_{2}$ emissions to a minimum, by reducing the number of trips and staying for extended periods of time when we travel. This is in compliance with our internal policy to engage in responsible travelling. If possible, our plan is to do some targeted but extended fieldwork, over a period of four to six weeks, in the summer of 2021.

Supplementary Materials: Video S1: Governing natural resources for food sovereignty in Africa, available at https://tinyurl.com/y46p7xsv.

Author Contributions: This discussion article and the underlying research and methodological approach were jointly conceptualized, written, reviewed and edited by S.L. and P.C. They are therefore equal co-authors. The same applies to project administration and funding acquisition. All authors have read and agreed to the published version of the manuscript.

Funding: This research was funded by the 11th Hour Project, The Schmidt Family Foundation. Funding for the follow-up research on Women's Communal Land Rights is also received from the 11th Hour Project.

Acknowledgments: We thank Stefania Errico for assisting with compiling background literature on the topic and for writing the consultancy report in the first phase of this project. We thank IRPAD and AFSA for co-hosting the two workshops in Mali and Uganda; Marine Lefebvre from SOS Faim Luxembourg, and Master students Ann-Christin Weiler and Alya Belkhodja for video filming during the two workshops; Ben Cook for post-editing, Larry Campbell for graphic design, Geetha Neelakatan, Moussa Sidibe for voice-overs in English and French; Susie Maugham, 
Sue Chambers, Geetha Neelakatan and Josh Elliot for support with administrative issues at Coventry University, and our colleagues at the Centre for Agroecology, Water and Resilience at Coventry University for providing valuable feedback on a draft version of the video. We greatly appreciate the financial support provided by the 11th Hour Project, The Schmidt Family Foundation, to undertake this research. We would like to especially acknowledge our friend, the late Stéphane Parmentier, who so sadly and unexpectedly passed away in June 2020. He composed the music for the video. His music page can be found here: https://soundcloud.com/user-34584257.

Conflicts of Interest: The authors declare no conflict of interest. The funders had no role in the design of the study; in the collection, analyses, or interpretation of data; in the writing of the manuscript, or in the decision to publish the results.

\section{References}

1. United Nations Declaration on the Rights of Peasants and Other People Working in Rural Areas. Resolution Adopted by the General Assembly on 17 December 2018, A/RES/73/165 21 January 2019. Available online: https://digitallibrary.un.org/record/1661560/files/A_RES_73_165-EN.pdf (accessed on 29 June 2020).

2. Claeys, P.; Edelman, M. The United Nations Declaration on the rights of peasants and other people working in rural areas. J. Peasant Stud. 2019. [CrossRef]

3. Doss, C.; Summerfield, G.; Tsikata, D. Land, gender and food security. Fem. Econ. 2014, 20, 1-23. [CrossRef]

4. Tsikata, D.; Yaro, J.A. When a good business model is not enough: Land transactions and gendered livelihood prospects in rural Ghana. Fem. Econ. 2014, 20, 202-226. [CrossRef]

5. Claeys, P. The creation of new rights by the food sovereignty movement: The challenge of institutionalizing subversion. Sociology 2012, 46, 844-860. [CrossRef]

6. Claeys, P. Human Rights and the Food Sovereignty Movement: Reclaiming Control; Routledge: London, UK, 2015.

7. Claeys, P. The rise of new rights for peasants. From reliance on NGO intermediaries to direct representation. Transnatl. Leg. Theory 2019, 9, 286-399.

8. Lemke, S.; Bellows, A.C. Bridging nutrition and agriculture. Local food-livelihood systems and food governance including a gender perspective. J. Technol. Assess. Theory Pract. Spec. Issue Feed. World Chall. Oppor. 2011, 20, 52-60. Available online: https://tatup.de/index.php/tatup/article/view/771 (accessed on 8 August 2020).

9. Lemke, S.; Bellows, A.C. Sustainable food systems, gender, and participation: Foregrounding women in the context of the right to adequate food and nutrition. In Gender, Nutrition, and the Human Right to Adequate Food: Toward an Inclusive Framework; Bellows, A.C., Valente, F.L.S., Lemke, S., de Lara, M.D.N.B., Eds.; Routledge: London, UK, 2016; pp. 254-340.

10. Lemke, S.; Delormier, T. Indigenous Peoples' food systems, nutrition and gender: Conceptual and methodological considerations. Matern. Child Nutr. 2017, 13, e12499. [CrossRef] [PubMed]

11. Alden Wily, L. Collective land ownership in the 21st century: Overview of global trends. Land 2018, 7, 68. [CrossRef]

12. Boone, C. Legal empowerment of the poor through property rights reform: Tensions and trade-offs of land registration and titling in Sub-Saharan Africa. J. Dev. Stud. 2018, 55, 384-400. [CrossRef]

13. Lemke, S.; Waters-Bayer, A. A Report on the International Colloquium of the High-Level Panel of Experts (HLPE) and the University of Hohenheim: Food Security and Nutrition in the Context of the 2030 Development Agenda: Science and Knowledge for Action; University of Hohenheim: Stuttgart-Hohenheim, Germany, 27 September 2016. Available online: https://gfe.uni-hohenheim.de/international-colloquium (accessed on 8 August 2020).

14. Pingault, N.; Caron, P.; Kolmans, A.; Lemke, S.; Kalafatic, C.; Zikeli, S.; Waters-Bayer, A.; Callenius, C.; Qin, Y. Moving beyond the opposition of diverse knowledge systems for food security and nutrition. J. Integr. Agric. 2020, 19, 291-293. [CrossRef]

15. Chambers, R. Rural Development: Putting the Last First; Longman: London, UK, 1983.

16. Pretty, J.; Guijt, I.; Thompson, J.; Scoones, I. Participatory Learning and Action: A Trainer's Guide; IIED: London, UK, 1995.

17. Reason, P.; Bradbury, H. (Eds.) The Sage Handbook of Action Research: Participative Inquiry and Practice; Sage: Thousand Oaks, CA, USA, 2008.

18. Coulibaly, M.; Claeys, P.; Berson, A. The right to seeds and legal mobilisation for the protection of peasant seed systems in Mali. J. Hum. Rights Prac. 2020, under review. 
19. Claeys, P.; Duncan, J. Do we need to categorize it? Reflections on constituencies and quotas as tools for negotiating difference in the global food sovereignty convergence space. J. Peasant Stud. 2018. [CrossRef]

20. McKeon, N.; Kalafatic, C. Strengthening Dialogue: UN Experience with Small Farmer Organizations and Indigenous Peoples; United Nations Non-Governmental Liaison Service: Geneva, Switzerland, 2009; 49p.

21. Claeys, P.; Duncan, J. Food sovereignty and convergence spaces. Political Geogr. 2019. [CrossRef]

22. World Café Method. Available online: http://www.theworldcafe.com/key-concepts-resources/world-cafemethod/ (accessed on 30 June 2020).

23. Fishbowl. Available online: https://www.unicef.org/knowledge-exchange/files/Fishbowl_production.pdf (accessed on 30 June 2020).

24. Errico, S. Governance of Land and Natural Resources in Africa. Overview of Legal and Policy Frameworks on Collective/Customary Land Tenure; Marginalisation; and Conflicts; Unpublished Report; Coventry University: Coventry, UK, 2019.

25. Krantz, L. Securing Customary Land Rights in Sub-Saharan Africa; Working Papers in Human Geography; Department of Economy and Society, Göteborg University: Göteborg, Sweden, 2015; Volume 1.

26. Scalise, E. Indigenous women's land rights: Case studies from Africa. In State of the World's Minorities and Indigenous Peoples; Minority Rights Group (MRG): London, UK, 2012.

27. Food and Agriculture Organization of the United Nations (FAO). The State of Food and Agriculture 2010-2011; Food and Agriculture Organization of the United Nations (FAO): Rome, Italy. Available online: http: //www.fao.org/3/a-i2050e.pdf (accessed on 30 June 2020).

28. Giovarelli, R.; Richardson, A.; Scalise, E. Gender and Collectively Held Land: Good Practices and Lessons Learned from Six Global Case Studies. Resource Equity and Landesa. 2016. Available online: https: //www.landesa.org/resources/synthesis-report-gender-collectively-held-land/ (accessed on 30 June 2020).

29. Bourke Martignoni, J.; Claeys, P. Without feminism there is no food sovereignty? Negotiating gender equality in the United Nations Declaration on the rights of peasants and other people working in rural areas. In Proceedings of the European Conference on Politics \& Gender (ECPG), Amsterdam, The Netherlands, 3-6 July 2019.

30. International Institute for Environment and Development (IIED). Innovation in Securing Land Rights in Africa: Lessons from Experience; IIED: London, UK, 2006.

(C) 2020 by the authors. Licensee MDPI, Basel, Switzerland. This article is an open access article distributed under the terms and conditions of the Creative Commons Attribution (CC BY) license (http://creativecommons.org/licenses/by/4.0/). 